\title{
Non-state actors and education as a humanitarian response: role of faith-based organizations in education for Syrian refugees in Turkey
}

Aslıhan Tezel Mccarthy (D)

\begin{abstract}
In the shadow of the Syrian conflict generating millions of displaced people, education provision for Syrian children has become one of the biggest challenges for Turkey. This paper sheds light on the role and rationale of faith-based humanitarian organizations in education provision for Syrian children in Turkey based on the interviews conducted with representatives of humanitarian organizations. The paper presents the wider socio-political context of Turkey to analyze the motivations of the Islamic humanitarian sector in exercising education facilities for a linguistically and culturally different population. In that context, this paper attempts to contribute to the fledgling literature on education as a humanitarian response from an institutional perspective.
\end{abstract}

Keywords: Refugee education, Faith-based organizations, Turkey, Syrian crisis, Education in emergencies, Humanitarian aid

\section{Introduction}

This paper addresses the operations of faith-based humanitarian organizations and their rationale for the measures taken for education provision for the non-camp Syrian children in Turkey. In unveiling the role of the Islamic humanitarian sector in exercising education facilities for a linguistically and culturally different population alongside the centrally governed national education system, this paper uses humanitarian aid and its education nexus as a theoretical framework.

Turkey retains a geographic limitation to its ratification of the 1951 UN Convention on the Status of Refugees (Refugee Convention), which means that Syrian people in Turkey, like many other refugees form non-European countries, in fact do not have "refugee" status. Therefore, Syrian people in Turkey are legally referred to as foreigners under "temporary protection" with a right to access to several public services including education. This paper, however, refers to the displaced people of Syria as refugees; that is, regardless of the differences in national

Correspondence: aslimccarthy@gmail.com

The Foundation For the Refugee Education Trust (RET), Ankara, Turkey and international legal conceptualization of "refugeehood." It also does not consider in detail the experience of refugees in arrival destinations as individuals. Rather, adopting an institutional approach, the focus of this study is how non-state organizations, particularly the faithbased non-governmental organizations (NGOs), respond to a humanitarian crisis in the education sector. Accordingly, the methodology for the research relies mainly on interviews with key informants from the Turkish Ministry of National Educations and non-state institutions-formally accredited by the Turkish Ministry of Interior as civil society organizations, associations, or foundations known as vakifs-involved in different aspects of education provision efforts for Syrian children.

Key informants were identified through a snowball sampling method to reach the staff actively occupied with education facilities for Syrian refugees. The bulk of the information provided is from the semi-structure interviews conducted with representatives of six faithbased NGOs operating in major provinces with a dense Syrian population like Hatay, Istanbul, Adana, Sanliurfa, and Gaziantep in 2016. The terms "faith-based humanitarian organization," "Islamic NGOs," and "vakifs" are 
used interchangeably, on the basis of their common ground in religious motives and use of Islamic charitable funds for social welfare promotion. This categorization is based on mission statements available at organization web sites and the representatives' own declarations during my interviews. Accordingly, faith-based humanitarian organizations can be described as civil society institutions or charity societies gathering people of particular Islamic ideology around a religiously oriented mission statement, generally to contribute to social welfare. These institutions are subject to laws of associations or foundations in the same manner as the secular ones not defining themselves in conjunction to any religious ideology.

Under the growing neo-conservatism and neoliberalism as a part of AKP's wider political project, Islamic NGOs have flourished since 2002 (Ünsaldi, 2013, Morvaridi 2013, Kaya 2015). Today, a great many humanitarian NGOs in Turkey have also religious visions. Although they institutionally take place outside the state, several of them have strong normative and ideological ties with state power (Keyman and Icduygu 2003; 228). In fact, for some scholars, AKP's social policy regime is based on Islamic references like charity which is rather a strategy used to reduce state responsibility for the provision of many services considered essential to securing social rights for citizens (Morvaridi, 2013). This research, on the other hand, looks into the repercussions of such a strategy in education provision as a basic right for refugees.

The interviews have been complemented by a literature review on the non-governmental actors in education as a humanitarian response. In addition to the abovementioned methods, this paper also greatly benefitted from early field observations, which I obtained during my previous experience in the field of refugee education as a volunteer at UNICEF Turkey and Save the Children Jordan; and as an administrator at the Turkish Ministry of National Education between late 2011 to early 2016.

Turkey was the first of Syria's neighbors to formally respond to the influx of Syrian refugees when the Government of Turkey declared an open border policy in line with its political interest in Syria. Syrian refugees were welcomed by the Turkish government with a language of hospitality highlighting their Muslim identity as guests. In only 3 years after the inception of the civil war, the number of Syrian refugees reached 3 million, $90 \%$ of whom settled in urban areas. Half of the Syrian population are children and the number of Syrian children at education age in Turkey has reached nearly 1 million, according to the head of Turkey's Disaster and Emergency Management Authority - AFAD (Idil 2017). There have lately been regulations in migration management to ensure basic rights like education for different kinds of immigrant children in Turkey. However, due to the scope and nature of the Syrian conflict, education problems of Syrian children overshadow problems faced by many other immigrants from different countries in Turkey.

Humanitarian organizations provide different services including education for refugees as a "surrogate for the state" in several immediate refugee-hosting countries like Jordan, Lebanon, and Iraq during the Syrian refugee crisis. The extending role of non-state actors emanates from the absence of governments which have adequate resources and institutional capacity in providing services for a great number of refugees (Kagan 2011). Turkey, however, stands out with its strong state institutions. Furthermore, Syrian refugees in Turkey make up only about 3\% of Turkey's population, which is much below the refugee/indigenous population proportion in Lebanon and Jordan (Mercy Corps 2016). Notwithstanding, several faith-based humanitarian organizations substitute the role of the state in education until the state establishes mechanisms for the integration of Syrian children into national education system. The education of Syrian refugees is specifically problematic in the context of Turkey and its centralized state institutions for a fundamental reason: most of the Syrian refugees have Arabic or Kurdish as mother-tongue and mother-tongue education is already a contested issue along with Turkish politics (Geerdink 2014). Furthermore, according to Kaya (2015), Islamization through the control of the state is evident in the changing social policies regarding faith-based organizations and education. In that context, examining the motives and approaches of faith-based organizations in education provision for Syrian refugees helps us increase our understanding of the dynamics of education as a humanitarian response in a delicate and controversial political context. This also provides necessary incentive for reconsidering education for Syrian refugees among the debates on Islamization of education in a secular nation-state.

\section{Non-state actors in education as a humanitarian response}

Whereas humanitarian action became the subject matter of several studies with considerable "interdisciplinary fragmentation" (Zwitter et al. 2014; 3, Roberts 1996, Kuijt 2014, Bragg 2015, Betts 2011, 2014, Agblorti 2011, Forte 2014, Ryfman 2007), until recently, education provision as humanitarian assistance remained understudied to a great extent (Sinclair 2002; 21, Davies and Talbot 2008, Aguilar and Retemal 2009, Bragg, 2015). One possible reason for this is that education was not viewed as a central pillar of the humanitarian response alongside nourishment, shelter, and health services until relatively recently (O’Rourke 2015, Burde 2014, Nicolai 
2003). Along with the global refugee crisis and the solidifying belief in education as a right for all children (including the displaced), the literature on the education dimension of humanitarian action is now growing (Anderson et al. 2011, Demirdjian 2012a, 2012b). In fact, the importance of educational responses during emergencies is now accepted by the global humanitarian assistance community. Indeed, in emergency situations, whether caused by human or natural forces, education serves many purposes as a tool for protection and prevention of harm and abuse (Sinclair 2001). It plays a critical role in normalizing the situation for the child and in minimizing the psychosocial stresses experienced when emergencies result in the sudden and violent destabilization of the child's immediate family and social environment (Pigozzi 1999).

To explore education as a part of humanitarian response, we should look into the theme of "education in emergencies" that came to the fore in the 1990s. Nicolai $(2003 ; 11)$ defines education in emergencies as a "set of linked project activities that enable learning structures to continue in times of acute crisis of long-term instability". Under the reforms to humanitarian response introduced in the early 2000s, there is a broad international institutional commitment to education in emergencies (Davies and Talbot 2008). International standards for emergency education contributes to the redefinition of a field of humanitarian intervention that covers education (Bromley and Andina 2010).

Unlike the other three pillars of humanitarian response-food, health, and shelter-education is never neutral, it is intrinsically ideological and political (Murray 2008). Thus, education as a humanitarian response can be conceptualized by introducing a framework for the relationship between education and politics. Paulson and Shields (2015) and Monaghan (2015) suggest that power relations between multilateral organizations and conflict-affected states determine the "legitimate knowledge," alternatively the curriculum to be used for displaced populations. For instance, UNRWA, as the main provider of education for Palestinian refugee children, is to consider the delicate power relations in peace and war while developing curriculum for the Palestinian refugees living in the neighboring Arab states (Demirdjian 2012a, 2012b).

Education provision may be seen to suffer during crisis and conflict when government support is absent or too weak. In cases when the education system becomes either idle or completely inactive in the absence of functioning government, international or non-governmental organizations carry out this function to a great extent. For instance, a study by Williams and Cummings (2015) shows that UNICEF took a leading role in education in Somalia between 1996 and 2010.
UNICEF working as a substitute for the government in Somalia is in line with the "pseudo nation-state" or "surrogate state" paradigm frequently referred to by Kagan (2011, 2012). "Surrogate state" is used to conceptualize the extending role of international and/or non-state organizations in providing basic services to refugees which normally should be provided by the state, but without the capacity to fully substitute for a host government. This phenomenon weakens the connection between territorial sovereignty and state responsibility for people who are present in their territory (Kagan 2011, 2012). Increasingly, non-state actors rather than the state provide education services for refugees in different parts of the world affected by crisis and conflicts. This phenomenon is especially problematic in cases when different political forces try to build legitimacy through school curriculum.

In cases when faith-based humanitarian organizations substitute secular nation-states in education provision, dynamics of education as a humanitarian response gets even more complicated given the narratives of conflict between Islam and the West in the contemporary world. The numbers of Islamic NGOs operating in the third world countries grew more than six times between 1980 and 2000 (Tønnessen, 2007). Islamic humanitarian organizations have also been actively involved in education as a humanitarian response in different parts of the world along with the rise of political Islam (Morvaridi 2013). Amid a chronic absence of effective state institutions, Islamic NGOs are observed to substitute the government in education provision along with other specific social domains in countries with Muslim population like Somalia. In Somalia, a well-structured network of Islamic charities has replaced the role of the Ministry of Education by establishing basic rules and regulations for a new education system (Saggiomo 2011; 60).

When talking about role of faith-based NGOs in education provision as humanitarian aid, we should bear in mind that it is a very complicated subject that makes generalizations difficult (Ferris 2011). Petersen (2011) suggests that the scope and aim of faith-based actors in education provision as a part of humanitarian relief programs differ along with the different understandings of Islam (p. 133, 137). Therefore, to unveil the scope and rationale of faith-based NGOs in education services for Syrian children, we will first have a look at the sociopolitical context of the country under study.

\section{Current issues on Turkish national education: AKP's education policy and non-state actors}

Education is the biggest state institution centrally governed by the Ministry of National Education (MoNE) in Turkey. Education is undertaken under the supervision and control of the state. According to Article 42 of 
the Constitution, everyone has the right to receive education. Primary and secondary education is free of charge in public schools. There are over 25 million students and 800.000 teachers in public education. According to MoNE sources, the annual budget of MoNE has gradually increased in the past 12 years (MoNE 2015). In line with the increasing share of education in general budget, there is a rapid transformation in public education system based on neoliberal and neoconservative policies effective under AKP rule (Soydan and Abali, 2014). That said private primary schools make up less than $10 \%$ while private secondary schools make approximately $20 \%$ of all schools in Turkey. All private schools in Turkey are subject to Law No. 625 and fall under the administration and inspection of MoNE. There is no curriculum freedom for private schools. All curricula are prepared by MoNE and private schools must use them. Curricular innovations in schools are not allowed (Cinoglu 2006). Considering the relative power and legitimacy of the state bureaucracy in the education sector, the Turkish State can be described as "strong/centralized" in the education sector. Although there has been considerable improvement in terms of access to education, Turkish education system still suffers from a big opportunity gap for children of different socioeconomic backgrounds in different regions.

The leading general aim of Turkish National Education defined by the Basic Law of National Education is to raise "individuals who are committed to Atatürk's reforms and principles, his concept of nationalism as defined in the Constitution; who adopt, protect and improve the national, moral, human, spiritual and cultural values of the Turkish nation; ...who are aware of their duties and responsibilities towards the Turkish Republic-which is a democratic, secular and social state ruled by law based on human rights ...." That said, reforms of AKP in the past two decades led to the domination of an ideology of religious nationalism based on Sunni Islam as opposed to the civic ethno-linguistic nationalism based on Turkish constitution. As put by Inal (2012), AKP presented a constructivist educational philosophy with a tendency to meet the needs of global competition; however, nationalism blended with Islamic references as the official ideology was redefined in revised text books.

AKP has been fiercely criticized by the secular opposition for systematically turning public schools into imam-hatip Schools in which religious courses are integrated with general/secular education. Imam-hatip schools teach Islamic history, Islamic law, Arabic, and Quran along with general courses like Mathematics. The number of imam-hatip schools increased by $73 \%$ between 2010 and 2014 (Ackerman and Calisir 2015). Furthermore, Arabic and entry level Islamic courses have been introduced to the general public education curriculum as elective courses starting from primary level onward.

Cinoglu (2006) argues that the public education in Turkey is not designed to meet the needs of a diverse society. A response to that argument in defense of AKP's education policies could be the fact that elective Kurdish courses were introduced into the middle schools in 2012, and a legislation was passed in 2013 to allow establishing private schools in Kurdish. Nevertheless, AKP's educational reforms are still far from being pluralistic since AKP's education policy aims raising "religious youth" and not generating an education content susceptible to cultural and linguistic differences. The idea of a religious "brotherhood" has become dominant in the textbooks published under AKP rule (Inal 2012; 23). AKP continues the historical state monopoly in education provision in terms of organization and content of knowledge to be transmitted through the centralized education system and curricula in primary and secondary education with a revised theme putting the Sunni-Islam into the forefront.

NGOs working in the field of religious education like the Onder Vakfi/Foundation, Ilim Yayma Vakfi/Foundation, and Ensar Vakfi/Foundation have been influential in formal education sector as stakeholders in government policies and sources of material support for Imam-hatip schools (religious public schools) and students under AKP government (Sarfati, 2012). Likewise, supportive education facilities such as academic scholarships granted by several faith-based NGOs are utilized as a means to disseminate the moral values based on Islam. Bulbuzade Vakfi in Gaziantep, self-defined as a humanitarian aid and education foundation, demonstrates the connection of education to Islamic ideology in their mission statement according to which their aim is to "raise a qualified generation that is devoted to Islamic moral values, responsible and well educated to represent Islam through the help of qualified and self-sacrificing educators sharing their values, to respond to the needs of society, ensuring the solidarity among Muslims and being the gate to the spiritual mission path."

Considering the importance of education as a longterm investment for accessing better life condition, it is commonplace for people of lower socio-economic status to become dependent on the educational opportunities presented as humanitarian aid and thus be in the centerline of the organizations providing aid for a long time. In that sense, rather than solving the structural inequalities, such humanitarianism can cause dependency among the recipients which can be exploited by political and ideological groups as the source of aid. Seizing the opportunities brought about by the neo-liberalism and neoconservatism under the rule of AKP, civil initiatives have been involved in education facilities through Vakifs in the near history of Turkey. Islamic movements, like 
the controversial Gülen Movement, have mobilized mainly through their networks in the education by opening hundreds of private schools, dorms, and study centers (dersane) with the pretext of quality education for the poor. This civil initiative recently turned into a national security issue in Turkey (Demiralp 2016).

Bearing the capacity of education for creating identity and social cohesion in mind, the next section will focus on the roles of humanitarian NGOs with a focus on Islamic organizations during the Syrian refugee crisis in education sector.

\section{Non-state actors and education response to the Syrian refugee crisis}

There were no regulations on the formation of educational institutions and the standards of educational services to be given out of the camps until 2013 when MoNE started looking for ways to regulate and standardize educational facilities for Syrian refugee children in and out of the camps. In a circular dated 16 September 2013, it was underlined that all education services to be provided in and out of the camps was to be planned, coordinated, and monitored only by the Ministry and the staff appointed by the Ministry locally. An important aspect of the circular was the fact that it envisaged a new curriculum and materials to be prepared in cooperation with Syrian National Coalition, alternatively the Syrian Interim Government. However, it was not until the entering into force of the new immigration law (Foreigners and International Protection Act no. 6458) in April 2014 that the education provision for Syrian refugees had a legal framework. According to FIPA, Temporary Protection Regime (TPR) education provision for Syrians inside and outside camps is to be under the control and responsibility of the MoNE. Following this development, MoNE circulated a notice titled "Education and Training Services for Foreigners (2014/21)" dated 23 October 2014. With reference to the recent law on international protection, the existing law on primary education on national education, the Convention on the Rights of the Child and International Covenant on Economic, Social, and Cultural Rights, this circular envisaged actions and procedures related to the coordination of education activities targeting foreigners including Syrians under temporary protection and refugees of other nationalities. That said, due their unprecedented number reaching 3 million, Syrian refugees have had a priority before the central education authorities. The important aspect of the circular for this study was the intention of MoNE to regulate all educational facilities that had been continuing with the initiative of different non-state organizations and private enterprises through an accreditation system naming them as "temporary education centers" (TECs). With that circular, Syrian schools operated by non-state actors without any formal status gained formal status. In TECs, Syrian teachers are employed and salaries are paid mainly by non-state actors. The course books are based on a revised Syrian curriculum. These books are published and distributed mainly via nonstate organizations. The language of instruction is Arabic and some Turkish courses are provided.

In 2015, there were 34 TECs in camps and 232 outside of camps in 19 provinces. In the 2015-2016 school year, total primary and secondary enrolment in TECs was 247,844 whereas there were only 75,748 Syrian students in public schools according to MoNE statistics. In 2017, the number of Syrian students in public schools reached 170,000 whereas the number of students in TECs reached 300,000. (CNN Turk 2017) The rise of the number of Syrian students in public schools is in line with Turkish government's agenda to integrate all Syrian children into public education system in the long run. The road map of the Turkish government regarding education of Syrian children is based on transforming the TECs with adequate physical structures into public schools and giving an end to TEC's presence (Haber, 2016). In that context, the implementations of Turkey regarding education as a humanitarian response differs from several developing countries affected by conflicts. While in Palestine or Somalia, non-state actors' role in education in emergencies becomes permanent as shown by Demirdjian (2012b) and Saggiomo (2011), Turkish state does not tolerate the existence of autonomous non-state structures within its national education system in the long run.

The roles of humanitarian organizations in the education sector can be summarized as operating TECs, renovation and refurbishment of schools, providing teachers incentives/salaries, developing, publishing and distributing educational materials, providing financial support to families, providing Turkish language courses and vocational trainings, and providing transportation. Syrian refugee crisis brought about a critical juncture in the history of national education that put humanitarian organizations as a substitute for the state education for a temporary period. While Williams and Cummings (2015) presented non-state actors as substitutes for state in education when government is absent or weak, Syrian refugee crisis in Turkey revealed that strong governments may also be substituted by non-state actors in times of emergencies. The centralized public education system has not proved capable of addressing the educational needs of a massive number of Syrian children as a culturally and linguistically foreign population. Operating flexibly out of state bureaucracy, humanitarian organizations were more effective than state institutions early on the crisis. They took initiatives much earlier than the state institutions. Indeed, initially education as a part of humanitarian assistance was broadly neglected by the Turkish state for non-camp refugees. As was revealed by 
the vice chairperson of the International Blue Crescent Relief and Development Foundation in my interview, "education was not a priority for any of the humanitarian aid bodies affiliated with the Turkish State like AFAD (Presidency of Disaster and Emergency Management) or The Turkish Red Crescent."

The early attitude of the Turkish government in responding to the crisis without addressing the education needs of refugees reflects a rudimentary understanding of humanitarian action which excludes education as a central pillar. This exclusion was based on concerns for voluntary repatriation. For instance, in a press release in 2012, the Minister of Education Omer Dincer stated that MoNE had no "intention to teach Turkish language to Syrian children" or integrate them into public schools as such policy would encourage Syrian people to stay in Turkey (MONE 2012). Several NGOs, on the other hand, incorporated education facilities into their humanitarian agenda with the inception of the crisis.

International Blue Crescent and Aziz Mahmut Hudayii Foundation commenced food and cash support for families and then provided incentives for children who attend school. That way, more Syrian families started sending their children to school. That was an effective way for increasing school enrolment of Syrian refugees. The utilization of education to reach the people in need is an approach similar to facilities of faith-based humanitarian organizations including the Christian organizations in other parts of the world as described by Horstmann (2011).

The beneficiaries of educational support by humanitarian organizations is not limited to Syrian children. Several humanitarian NGOs have refurnished the public schools allocated as TECs for the afternoons. Turkish children attending these schools in the morning benefit from the improvements in their schools. In that respect, education as a part of humanitarian aid for refugees contributes to education in the host communities as well.

Humanitarian organizations tend to follow the general principles of education in emergencies regarding a community-based approach. Many NGOs operating TECs have unofficially recruited refugees as teachers and school administrators (Syrians did not have work rights until early 2016). Despite the fact that they are paid very little, the NGO schools have in fact become means to increase financial self-reliance of refugees. NGOs also provide vocational training or language courses for adults and young people, which help create a self-sustainable refugee population.

Another important role of humanitarian organizations in education has been supplying suitable educational materials to be used in Turkey. Publication and circulation of course books required financial and organizational support of many different NGOs. Syrian Education
Association revised the textbooks in cooperation with the Syrian Interim Government. As a result, all "impurities" of the Assad regime were removed from 204 books for different grades. These books were printed and distributed in Turkey and "liberated areas" in Syria with the financial support from Qatar with the help of humanitarian organizations (Interview with Syrian Education Association board member, 13.09.2015, Istanbul). As suggested by Murray (2008), education, even in an emergency context, is intrinsically political. Revision of textbook in line with the stance of the Syrian political opposition shows the political character of education as a humanitarian response. Assisting development and circulation of education content that aims to consolidate the rule of opposition powers, humanitarian organizations become part of the politicization of education even though they do not intend to do so. In fact, although humanitarian aid requires neutrality, it is hard to avoid fusing philanthropy with politics and ideology as argued by Horstmann (2011) with his study on the Christian humanitarian organizations. In the next section, I will elaborate more on the political and ideological dimension of education as a humanitarian repose through analyzing the motives to the Islamic humanitarian NGOs in education provision for Syrian refugees.

\section{Faith-based organizations in education provision for Syrian refugees: philanthropy or religious nationalism?}

Syrian refuge crisis has shown that acts of Islamic humanitarianism in Turkey are not limited to distributing aid. Education provision has become an essential element of faith-based humanitarianism in Turkey. The response to the education dimension of the Syrian refugee crisis has shown that the impetus for education as humanitarian aid is beyond the internationally recognized goals of emergency education. It is also beyond a simple Islamic obligation to help the needy but an extension of religious nationalism.

Faith-based humanitarian NGOs tend to base their motives in education provision for Syrians on (1) "Islamic brother/sisterhood" and (2) the danger of assimilation by secular Western ideas. The representatives of faith-based NGOs interviewed explained their involvement in educational facilities as an "Islamic obligation" to help other Muslim people. Thus, emergency education as a useful mechanism to reduce the traumas of war and prevent exploitation of the vulnerable children gains a new dimension as a way of validating Islamic faith. The chairperson of a local humanitarian NGO, AY-DER explained their aim in involvement in education provision for Syrian refugees as:

Our aim is to supply Syrian brothers/sisters with true knowledge and help them gain good manners, raise their 
degrees and qualities to become individuals useful for society, and to build bridges between two societies through joint activities with Turkish students. (Interview with AY-DER chairperson, 10.11.2015, Adana).

One of the greatest problems faced by the Syrians immigrating to Turkey or to Europe via Turkey is seen as their inability to retain their cultural identities, languages, and beliefs. In that context, education is affiliated with a fight against exploitation and assimilation by the Western values. There is an increasing concern among the Turkish faith-based NGOs that Christian missionary institutions would utilize the education gap to estrange Syrian children and youth from their moral values and force them to move away from their identities for better life and career opportunities in the West. For the IHH-Humanitarian Relief Foundation education sector manager "unless the Syrian schools in Turkey and Syria are supported, brain drain to Europe will continue by means of missionary organizations and Syrian youth will be assimilated" (from interview dated 11.11.2015, Hatay). There is no evidence for the presence of missionary organizations providing education for Syrian refugees in Turkey, yet considering the argument of Horstmann (2011) on the link between humanitarian aid and proselytizing, the fears of Islamic NGOS in Turkey might have grounding. To what extent the Islamic NGOs provide assistance to Syrian refugees regardless of faith, on the other hand, is questionable, especially when the ethnic and religious differences among Syrian refugees are considered.

The stance of the faith-based NGOs resembles religious nationalism promoted by AKP associating social justice with Islamic identity. In that context, in providing education as a humanitarian response, faith-based NGOs have an Islamist-humanist mission, a civil version of the AKP's religious nationalism. The education needs of Syrian refugees as the "brothers in faith" are met through zakat funds (Islamic donations). Agreeing with the fact that it also is an effective way to increase schooling among the refugees, I shall also relay that education for Syrian refugees has become an extension of a "religious welfare project" likely to create dependency among the recipients and this dependency might potentially be exploited by different Islamic movements (Zencirci 2015, 548).

In many TECs operated by faith-based NGOs, majority of the classes are held in Arabic language with religious courses included. While the secular NGOs operating schools for Syrians encourage girls and boys to coexist in the same classrooms regardless of their ages, for some faith-based NGOs, education for Syrian refugees should be based on Islamic values segregating girls and boys in secondary schools just like the ImamHatip schools in Turkey. Despite arguing for equal educational opportunities for women, the AY-DER
(Adana Humanitarian Aid Foundation) chairperson stated that education for Syrian refugees should be gender segregated above primary school unless there are special conditions. That is because "men and women are now allowed to be present together according to Islam and Syrian people are Muslims" (Interview with AY-DER chairperson, 10.11.2015, Adana). AY-DER chairperson believes that gender-segregated education would increase the schooling rates of Syrian girls and increase the socio-economic advantages for Syrian women. Indeed, in certain cases, compromises can be made in universal values of gender equity in the education programs to increase attendance. However, it should be born in mind that such compromises constitute a slippery ground in a secular state where education has been systematically Islamised in the past two decades.

Efforts of many humanitarian NGOs in education provision may be futile and palliative rather than being a durable solution for the education problem of the refugees, considering that the education given in TECs greatly prepares the children for repatriation rather than integration. When asked about the reasons of adopting such an approach, similar answers were given by all the faith-based humanitarian organizations. First of all, they do not want to encourage the refugees to stay. The argument is that Syrian refugees are provided education in Turkish curriculum and language, they would have a perception that Turkish state wishes them to settle in Turkey. TECs give education to Syrian children in Arabic to prevent them from forgetting their mother tongue, besides this approach is argued to be preferred by the Syrian parents themselves (Interview with Diyanet Foundation Expert, 28.09.2015, Ankara).

Rather than being shut down as illegal schools, TECs were placed under state supervision. After MoNE established a legislative base for the education of Syrian refugees in 2014, it also formed a framework for cooperation with non-state bodies operating TECs (Interview with MoNE Expert, 08.03.2016, Ankara). Under the new regulations, coordinator principals were appointed to TECs by MoNE to take the education facilities provided by non-state agents under control. With such regulations, the state also hijacked the system originally established by non-state initiatives like faith-based NGOs. My interview with the AY-DER chairperson revealed that MoNE does not want the NGOs to take initiative at policy level or take managerial roles at TECs. MoNE prefers NGOs to be material suppliers regardless of the field experience they possess. In that respect, it can be argued that despite the substitution of state institutions by humanitarian NGOs, the state has not relinquished its supervisory position in education. Rather it maintains a patrimonial attitude and continues the centrist mentality by controlling NGOs. 
Despite the superior position of the state, faith-based NGOs tend to be seen as the reliable partners while those with clear secular agendas tend to be left out (Interview with Yuva Association, 02.02.2016). Among the most reliable partners for MoNE are GONGOs, government organized non-governmental organizations created for promoting issues that the government wants to bring attention to or advance its interests. Diyanet Foundation (a non-governmental extension of the Presidency of the Religious Affairs working for the promotion of Islamic values) is highly favored by MoNE for cooperation. This in fact reflects AKP's religious sentiment in education of the Syrian refugees. Although the Diyanet Foundation had not been involved in formal education within Turkey prior to the crisis, it is now seen as an alternative to other non-state organizations who allegedly have the potential to "exploit and abuse the situation" in education for Syrian refugees (from the interview with a MoNE expert). In that respect, the state makes uses of faith-based humanitarianism as a way of extending its political agenda in education. Until the state reconceptualizes its legislative framework to allow for education in Arabic language, faith-based NGOs who have similar ideological agendas enact the government's Islamic brotherhood discourse for Syrian refugees.

\section{Conclusion}

This article attempted to contribute to the fledgling literature on education as a humanitarian response through an institutional perspective that aims to reflect the increasing role of faith-based NGOs in education which coincided with the refugee crisis in Turkey. During the refugee crisis, various faith-based humanitarian NGOs found themselves a place in the education sector for refugees. This has led to a situation of temporary substitution, with faith-based humanitarian NGOs among other non-state actors acting as surrogates/subsidiaries to fill the service gap in refugee education until the state develops the capacity to deal with the issue by itself.

Providing education for Syrian children as non-citizen entities is a very complex process including a variety of state and non-state actors in Turkey. The power relations among these actors and socio-political context of the country as well as the particular needs of the diaspora has turned education provision for refugees into a problem that has generated its own paradigm. In that context, education as a humanitarian response is beyond being only philanthropic action. Beneath the surface of philanthropy, there are political and ideological motivations that encourage humanitarian organizations to spend energy and resources on education provision for refugees.

While the potential for tension with the centralized education system is apparent, this paper has found out that the rationale of faith-based humanitarian NGOs for providing education as humanitarian response for Syrian refugees coheres with the ideology of Sunni-Islamist nationalism promoted by the ruling party. Accordingly, these organizations aim at preventing the "assimilation" of Syrian children and conserve their religious identities as Sunni-Muslims. Analyzing the ambitions of six faithbased humanitarian organizations in education provision for Syrian refugees in Turkey, the finding of this paper is that an Islamisation of discourse prevalent in statecivil society relations and education can be traced to education as a humanitarian response in Turkey.

\section{Abbreviations \\ AFAD: Presidency of Disaster and Emergency Management; AY-DER: Adana Humanitarian Relief Foundation; FIPA: Foreigners and International Protection Act; IGAM: The Research Centre on Asylum and Migration; $\mid \mathrm{HH}$ : Humanitarian Relief Foundation; MoNE: Ministry of National Education; NGO: Non-governmental organizations; TEC: Temporary education center; TPR: Temporary protection regime}

Availability of data and materials

The datasets used and/or analyzed during the current study are available from the corresponding author on reasonable request.

\section{Funding}

This research was supported by the TUBITAK Grant No: 2214-A

Ethics approval and consent to participate

Formal consent had been taken from the related organizations before the interviews were conducted.

\section{Consent for publication}

I hereby give my consent for the publication of my work in the Journal of International Humanitarian Action.

\section{Competing interests}

The author declares that she has no competing interests.

\section{Publisher's Note}

Springer Nature remains neutral with regard to jurisdictional claims in published maps and institutional affiliations.

Received: 24 March 2017 Accepted: 25 October 2017

Published online: 13 November 2017

\section{References}

Ackerman, X, and Calisir E. 2015. Erdogan's assault on education: the closure of secular schools. In: Foreign Affairs, December 23. https://www.foreignaffairs. com/articles/turkey/2015-12-23/erdogans-assault-education. Accessed 17 Feb 2017

Agblorti, S. K. M. 2011. Humanitarian assistance to refugees in rural Ghana: implications for refugee-host relations. Nor J Geogr. Available at: http:// www.tandfonline.com/doi/abs/10.1080/00291951.2011.574319?journalCode= sgeo20. Accessed 23 Jan 2014

Aguilar P, Retemal G (2009) Protective environments and quality education in humanitarian contexts. Int J Educ Dev 29:3-16

Ahmadoun S. 2014. Turkey's policy towards Syrian refugees. In: German Institute for International and Security Affairs. No. 47, pp. 1-4. https://www.swp-berlin. org/fileadmin/contents/products/comments/2014C47_ahmadoun.pdf

Anderson A et al (2011) The right to education for children in emergencies. Int Humanit Legal Stud 2:84-126

Aras, B. \& S. Yasun. 2016. The educational opportunities and channelings of Syrian refugee students in Turkey: Temporary Education Centers and Beyond, IPC-Mercator Policy Brief. http://research.sabanciuniv.edu/29697/1/ syrianrefugees.pdf. Accessed 5 Dec 2016.

Bell L, Stevenson H (2006) Education policy; process; themes and impact. Routledge, London 
Betts, A. 2011. International cooperation in the refugee regime in A. Betts \& G. Loescher (Eds) Refugees in International Relations, Oxford: Oxford University Press

Betts A (2014) The global governance of crisis migration. In: Martin SF et al (eds) Humanitarian crisis and migration: causes, consequences and responses. Routledge, New York

Bragg C (2015) Disaster management and multilateral humanitarian aid: parallelism vs. combined forces. In: Gibbons P, Heintze H-J (eds) The humanitarian challenge. Springer International Publishing, Switzerland. doi:10.1007/978-3-319-13470-3

Bromley P, Andina M (2010) Standardizing chaos: a neo-institutional analysis of the INEE minimum standards for education in emergencies, chronic crises and early reconstruction. Compare 40(5):575-588

Burde D (2014) Schools for conflict or for peace in Afghanistan. E-book: Columbia University Press, New York

Cinoglu M (2006) Private education as a policy tool in Turkey. Int Educ J 7(5):676-687

CNN TURK, 2017. Turkiye'deki Suriyeli Ogrenci sayisi Aciklandi. May 31. Available at https://www.cnnturk.com/turkiye/turkiyedeki-suriyeli-ogrenci-sayisiaciklandi. Accessed 10 Sept 2017

Davies L, Talbot C (2008) Learning in conflict and postconflict contexts. Comp Educ Rev 52(4):509-518

Demiralp, S. 2016. The breaking up of Turkey's Islamic alliance: The Akp-Gulen conflict and implications for Middle East studies. Available at http://www. rubincenter.org/2016/04/the-breaking-up-of-turkeys-islamic-alliance-the-akpgulen-conflict-and-implications-for-middle-east-studies/. Accessed 04 Aug 2016

Demirdjian L (2012a) Introduction: education, refugees and asylum seekers-a global overview. In: Demirdjian L (ed) Education, refugees, and asylum seekers: education as a humanitarian response. Continuum International Publishing, London, pp 1-33

Demirdjian $L$ (2012b) The provision of education in the Palestinian refugee camps, in Lebanon. In: Demirdjian L (ed) Education, refugees, and asylum seekers: education as a humanitarian response. Continuum International Publishing, London, pp 105-126

Ferris E (2011) Faith-based humanitarianism: it is complicated. J Refug Stud 24(3):606-625

Forte MC (2014) Imperial abduction lore and humanitarian seduction. In: Forte MC (ed) Good intentions: norms and practices of imperial humanitarianism. Alert Press, Montreal

Geerdink, F. 2014. Kurds not giving up on mother tongue. Available at http:// www.al-monitor.com/pulse/originals/2014/09/turkey-kurds-education-inmother-tongue-schools.html. Accessed 03 May 2016

Gershberg, A. I. 2005. Towards an education decentralization strategy for Turkey: guideposts from international experience: policy note for the Turkey Education Sector Study. WorldBank online source. Available at http:// siteresources.worldbank.org/INTTURKEY/Resources/361616-1142415001082/ Turkey_decentralization_strategy.pdf. Accessed on 10 Jan 2015

Haber Turk, 2016. MEB, Suriyeli çocukların eğitimi için yol haritasını belirledi. August 22. Available at http://www.haberturk.com/gundem/haber/1285903 meb-suriyeli-cocuklarin-egitimi. Accessed 01 Sept 2017

Horstmann A (2011) Ethical dilemmas and identifications of faith-based humanitarian organizations in the Karen refugee crisis. J Refug Stud 24(3):513-532

Icduygu A (2011) Interacting actors: the EU and civil society in Turkey. South Eur Soc Polit 16(3):381-394

Idil N. 2017. Number of Syrian children at education age reaches almost 1 million in Turkey. In: Hurriyet Newspaper. Available at http://www.hurriyetdailynews.com/ number-of-syrian-children-at-education-age-reaches-almost-1-million-in-turkey-. aspx?PagelD=238\&NID=112603\&NewsCatID=341. Accessed 14 Jul 2017

Inal, K. 2005. Türkiye'de Devlet Destekli Sivil Toplum Örgütlerinin Eğitimde Eșitsizliğe Yaklaşımları. Sivil Toplum: Dusunce \& Arastirma Dergisi 3(12):39-50

Inal K (2012) The education politics of the AKP: the collapse of public education in Turkey. In: Inal K, Akkaymak G (eds) Neoliberal transformation of education in Turkey: political and ideological analysis of education reforms in the age of AKP. Palgrave Macmillan, New York

Irrera D (2011) Civil society and humanitarian action: NGOs' roles in peace. Perspectives 19(1):85-106

Kagan, M. 2011. We live in a country of UNHCR: the UN surrogate state and refugee policy in the Middle East. February 2011, ISSN 1020-7473. Available at: http:// www.refworld.org/docid/4d8876db2.html. Accessed on 03 April 2015

Kagan, M. 2012. The UN "Surrogate State" and the Foundation of Refugee Policy in the Middle East. Scholarly Works. Paper 781. Available at http:/scholars.law.unlv.edu/ cgi/viewcontent.cgi?article=1803\&context=facpub. Accessed on 31 May 2014

Kaya A (2015) Islamisation of Turkey under the AKP rule: empowering family, faith and charity. South Eur Soc Polit 20(1):47-69
Keyman F, Icduygu A (2003) Globalization, civil society and citizenship in Turkey: actors, boundaries and discourses. Citizensh Stud 7(2):219-233

Kuijt E (2014) A humanitarian crisis: reframing the legal framework on humanitarian assistance. In: Zwitter A, Lamont C, Heintze H, Herman J (eds) Humanitarian action: global, regional and domestic legal responses. Cambridge University Press, Cambridge. doi:10.1017/CBO9781107282100.009

Mercy Corps, 2016. Quick facts: what you need to know about the Syria crisis: Iraq, Jordan, Lebanon, Syria, Turkey. Available at https://www.mercycorps.org/ articles/iraq-jordan-lebanon-syria-turkey/quick-facts-what-you-need-knowabout-syria-crisis. Accessed 01 Jul 2016

Monaghan C (2015) Changing the prisms: new theoretical approaches for education in emergencies. In: Gross J, Davies L (eds) The contested role of education in conflict and fragility. Sense Publishers, Rotterdam

MONE, 2012. Interview with the Minister. Press Release. Available at http://www. meb.gov.tr/haberler/2012/03102012.pdf. Accessed 01 May 2016

MONE, 2015. MEB has the greatest share of the Turkish budget. Press Release. Available at http://www.meb.gov.tr/meb-has-greatest-share-of-the-turkishbudget/haber/8338/en. Accessed 03 Sept 2016

Morpeth R, Creed C (2012) Reframing basic education to deliver education for all: flexible provision and enabling frameworks, open learning. J Open Distance E Learn 27(3):201-214

Morvaridi B (2013) The politics of philanthropy and welfare governance: the case of Turkey. Eur J Dev Res 25:305-321. doi:10.1057/ejdr.2012.54

Murray H (2008) Curriculum wars: national identity in education. Lond Rev Educ $6(1): 39-45$

Nicolai S (2003) Education in emergencies; a toolkit for starting and managing education in emergencies. Save the Children, London

O'Rourke J (2015) Education for Syrian refugees: the failure of second-generation human rights during extraordinary crises. Albany Law Rev 78(2):711-738

Paulson J, Shields R (2015) Conflict-fragility-education: issues in conceptualization and measurement. In: Gross J, Davies L (eds) The contested role of education in conflict and fragility. Sense Publishers, Rotterdam

Petersen MJ (2011) Islamizing aid: transnational Muslim NGOs after 9.11. Int Soc Third Sect Res John's Hopkins Univ 23:126-125, published online. doi:10.1007/s11266-011-9185-5

Pigozzi MJ (1999) Education in emergencies and for reconstruction: a developmental approach. In: United Nations Children's fund working paper. UNICEF, New York

Roberts A (1996) Humanitarian action in war: aid, protection and impartiality in a policy vacuum. Oxford University Press for the International Institute for Strategic Studies, London

Ryfman P (2007) Non-governmental organizations: an indispensable player of humanitarian aid. Int Rev Red Cross 89(856):21-45

Saggiomo V (2011) From charity to governance: Islamic NGOs and education in Somalia. Open Area Stud J 4:53-61

Sarfati Y (2012) The politics of religious education in Turkey. In: Krishna-Hensel SF (ed) Religion education and governance in the Middle East. Routledge, New York

Sinclair M (2001) Chapter 1: education in emergencies. In: Crisp J et al (eds) Learning for a future: refugee education in developing countries. United Nations Publications, Geneva

Sinclair M (2002) Planning education in and after emergencies. UNESCO International Institute for Educational Planning, Paris

Soydan T, Abali HG (2014) Changes in the field of finance of education in Turkey within the context of neoliberal policies. J Critic Educ Policy Stud (JCEPS) 12(1):361-390

Tønnessen V (2007) Faith-based NGOs in international aid: humanitarian agents or missionaries of faith? Forum Develop Stud 34(2):323-342

UNHCR, 2014. Number of Syrian Kurds fleeing to Turkey nears 140,000; humanitarian needs mount. Available at http://www.unhcr.org/en-au/news/ latest/2014/9/54214ed19/number-syrian-kurds-fleeing-turkey-nears-140000humanitarian-needs-mount.html. Accessed 05 Jul 2015

Ünsaldi, L. 2013. Between neoliberalism and morality: The Muslim conception of development in Turkey. Int Develop Policy. Available at http://poldev.revues. org/1847. doi:10.4000/poldev.1847. Accessed on 07 Jul 2017

Williams JH, Cummings WC (2015) Education from the bottom up: UNICEF's education programme in Somalia. Int Peacekeep 22(4):419-434. doi:10.1080/13533312.2015.1059284

Zencirci G (2015) From property to civil society: the historical transformation of Vakifs in modern Turkey (1923-2013). Int J Middle East Stud 47:533-554

Zwitter A, Lamont C, Heintze H, Herman J (2014) Introduction. In: Zwitter A Lamont $\mathrm{C}$, Heintze $\mathrm{H}$, Herman J (eds) Humanitarian action: global, regional and domestic legal responses. Cambridge University Press, Cambridge 